\section{連載講座 II.}

わが国の動力炉開発, (その11)

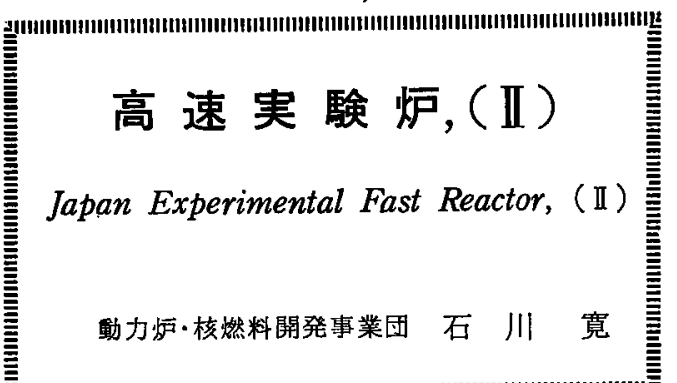

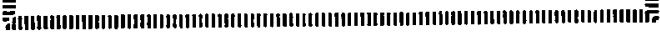

I.はしが

I. 高速実鍳炉の建設計画

II. 高速実数师の概要

\section{I.はしがき}

わか国の原子力発電は，当分の間，軽水炉をはじめ とする在来型师が主流を占めるるのと考えられる。し かし，わか国エネルギーの安定供給の確保，原子力産 業基盤の確立などの観点からいって，わが国の原子力 発電が長期間にわたって外国で開発された在来型炉の みに依存することは，必ずしも望をしいことではな い。したがって，高速堌殖炉および新型転换师の実用 化儿より，核燃料の有効利用をはかるととる，国内 の自立をはかることが重要であると考えられ，動力炉 開発の基本方針が原子力委員会により下記のように定 められた。

「核燃料の安定供給と有効利用を蛙かり，かつ原子力 発電の有利性を最高に発揮せしめるため, 適切な動力 沪を自主的に開発することは，エネルギー政策におけ る重要課題であるととすに産業基盤の強化と科学技術 水準の向上に大きく寄与するものである。

このよ5な観点から，高速増殖炬扰よび新型転換炉 をそれぞれ昭和 60 (1985) 年代の初期括上び昭和 50 （1975）年代の前半に実用化するため，原型炉の建設運 転までの開発を目標とし，関係各界の総力を結集して その開発を推進するるのとする。

高速增殖炉の開発については，Pu とUの湿合酸化 物系燃料を用いる $\mathrm{Na}$ 冷却型高速堌殖訬を開発するこ とを目標として研究開発を進めるるのとする。高速実 験炉は，高速原型炉の開発に必要な技術的経験を得る ととるに，完成後は燃料材料などの照射施設として利 用することを目的として，熱出力約 10 万 $\mathrm{kW}$ 程度のる のを1973年頃臨界汇至らせることを目標とする。」
このような高速増殖炉の開発計画を実現すること は，わが国において，かって経験のない大規模な計画 であり，関係各界の総力を結集してこれを「国のプ ロジェクト」として実施する必要がある。このため， 動力炉.核然料開発事業団か; 1967 年10月に設立され， 高速増殖炉怙よび新型転換沪の開発を計画的かつ效率 的に推進することになった。

動力炉・核燃料開発 事業団(以下動燃)は，日本原子 力研究所，大学，国立試験研究機関，原子力産業界，電力 界など関係各界の協力を得て，研究開発を実施すると ともに，その進捗状況の把握拁よび成果の評価を行い つつ，高速実験炉，高速原型炻，新型転換炉などの設 計，建設，試験的運転などを総合的に行うことになって いる。またこの動燃隹研究開発を効率的に推進するた め，その業務の一部を関係各機関扰よび民間企業に委 託するととるに，諸外国との国際協力も積極的に進め ている。

\section{II . 高速実験炉の建設計画}

高速增殖师は，炉内で消費される核燃料よりるより 多い核燃料が新たに生成されることから，核燃料資源 を有効に利用し，低廉なエネルギーコストを実現する に最る有望な原子炉である。高速增殖炉開発の目標は 高い増殖比と経済性の達成にある。そのためには $\mathrm{Pu}$ を燃料として液体 $\mathrm{Na}$ を冷却材使用する原子炉が一 般に有望であると考它られており，各国における開発 努力もその主力がこの炉型に向けられている。

わが国に拈ける高速実験师の設計研究は, 1962年に 日本原子力研究所以招いて開始され，第 1 次概念設計 を経て1968年 3 月に第 2 次概念設計が完成した。その 成果は1968年 6 月に動燃に引き継がれ，以後の作業は 動燃が中心となって推進することになった。動燃は第 2 次概念設計に基ついて，第 3 次概念設計を国内の原 子力関係 5 社に依頼し，また第 2 次概念設計の検討·評 価をフランス原子力公社(CEA)に体頼した。これら 第 3 次概念設計怙よびフランス原子力公社による検討 評価の結果は1969年 3月にまとめられた。動燃に打い ては同年 4 月上り第 3 次概念設計書およびフランス原 子力公社の報告書を詳細に検討し，高速実験师の設計 をさらに調整する作業を実施し，1969年6月30日にこ の実験炉の設置に関寸る許可申請を内閣総理大臣宛提 出した。

高速実験少の目的は，わが国で初めて建設される $\mathrm{Na}$ 冷却高速炉の設計，製作，建設および運転を通じて 高速原型炉さらには将来の大型の実用高速炉の建設に 


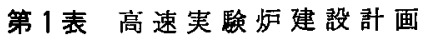

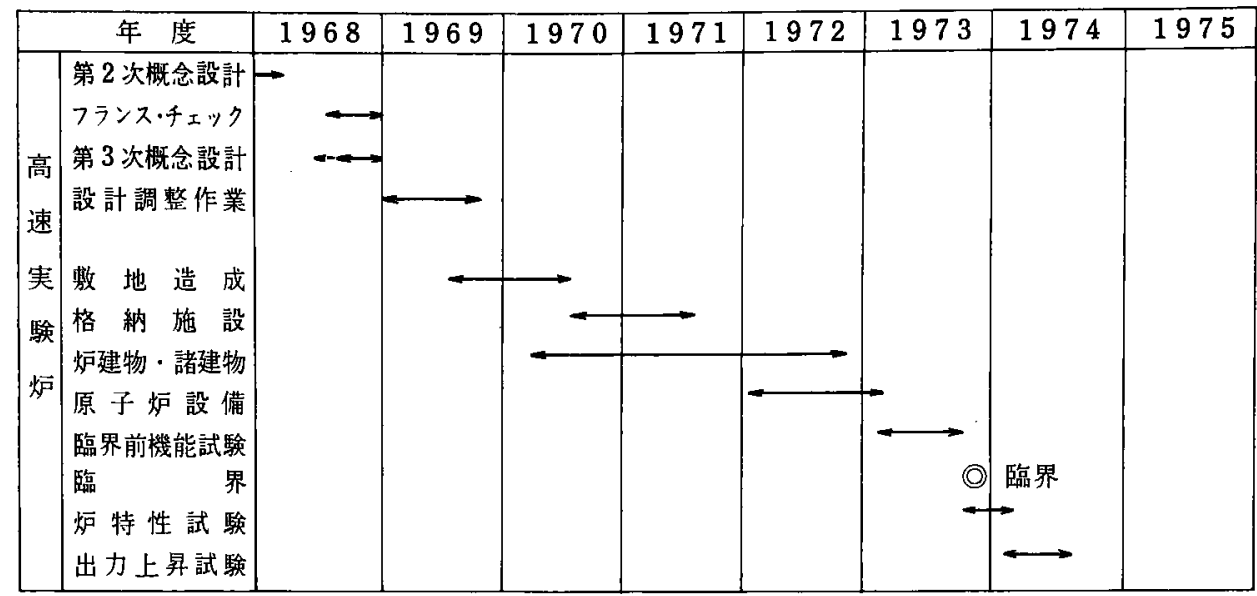

当って予想される各種の技街的諸問題を自ら体驗し解 決することである。また完成後は，わが国に打ける高 速増殖师用燃料扣上び材料の開発のための照射施設と して，わが国の高速增殖炉の開発に利用されるすのと 期待される。

高速実験炉は第 !表に示すように，1973年末臨界学 目標に動燃大洗事業所に建設される予定である。この 実験师はわが国で初めての $\mathrm{Na}$ 冷却高速炬であるの で，その安全性と信頼性に最も重点を和いて設計が行 われている。また実験师用燃料をはじめ各種の機器設 備の製作，建設はできる限り国内技術により行うこと を目標としている。このため実験师の建設に関連 し て，実験炻用の試作然料をイギリスの Dounreay 高速 炉,フランスの Rapsodie 高速悟,フメリカの Enrico Fermi 高速炉などの海外高速炉で照射試験を行うほ か，日本原子力研究所の高速臨界実験装置に上る実験 炉炉心の模擬実験, 動燃大洗事業所に打ける炉容器, 回 転プラグなど归本体主要部のモックフップ試験ならび にNa ループを用いた主循環ポンプの試験などの研究 開発計画が進んでいる。

実験炉は動燃が日本原子力研究所から借用した茨城 県東资城郡大洗町成田町の動然大洗事業所敷地内に設 置される予定である。大洗事業所の敷地の面積は約 $480,000 \mathrm{~m}^{2}$ である。本敷地は，水戸市の東南東約 14 $\mathrm{km}$ にあり，帴地扰よびその周辺は海抜約 $40 \mathrm{~m}$ 前後の 比較的平坦な山林拉よび畑地であり，㜞地の東側は国 道51号線をへだてて太平洋に面した海岸である。

実験炡は研究開発的要素を大幅に含むるのであるの で，安全審查は現在慎重に行われている。実験炉引合 仕様書は1969年 9 月 9 日に動燃加ら原子炉製造業者に
説明され，11月には見積仕様書扰よび見積金額が提出 される予定になっている。安全審査が完了し，契約交 涉が妥結すれば，実験炉の建設に着工することとなる が，大洗の現地では建設予定地の地盤載荷試験, 整地 招よび砂利道工事, 建設現場事務所新設などの準備工 事が進められつつある。

\section{III. 高速実験炉の概要}

高速実験泟は，前述の目的に沿って，わが国におけ る実験少としての役割を十分果し得るょう早期完成と 安全かつ確実な運転ができることを基本的な方針とし て設部されている。この実験炉の最終目標出力は 100 $\mathrm{MWt}$ であり，プラントの設計はこの熱出力 100,000 $\mathrm{kWt}$ を目標に設計されている。しかしながら，この原 子炉はわか国侸設置される最初の Na 冷却高速炉であ ることを勘案し，今回の設置訐可に関する申請におい ては，第 1 期の原子出出力として50 MWt 採用して 申請した。したがってここで述べる実験师の数值は この50 MWt K対するすのである。

動燃としては，今後の研究開発，実験炬の建設運転 による試験結果ならびに経験に基づいて，今回申請し た50 MWt の出力運転成功後はできるだけ早期に最終 目標出力に到達するよ5段階的に出力の上昇をはかる 考宇である。

高速実験炉の炉心は，U·Pu の混合酸化物燃料を使 用した炉心領域を，隇損Uを使用したブランケット然 料でかこんだすので，液体 Na で冷却される。炻心て 発生した熱を除去するための冷却系統は，全く同一の 2 つの回路からなり，それぞれの除熱能力は $50 \mathrm{MW}$ である。各冷却回路はそれぞれ１次冷却系，中間熱交 
第 2 表 高速実験师の主要目表

\section{1. 核 特 性}

炉心体積(制御棒含む) (l) 252

实心部組成比(\%)

㜣料/命却材 $/$ 構造材 $=38 / 41 / 20$

半径方向ブランケット組成此(\%)

燃料/命却材 $/$ 粠造材 $=48 / 32 / 18$

軸方向ブランッット組成比(\%)

燃料/冷却材/構造材 $=38 / 41 / 20$

㜣料ペレット密度

炻心燃料 $\left(\mathrm{PuO}_{2}-\mathrm{UO}_{2}\right) \quad 94 \%$ T.D.

ブランルット燃料 $\left(\mathrm{UO}_{2}\right) \quad 94 \%$ T.D.

フイソトープ組成比(\%)

炉心燃料 ${ }^{239} \mathrm{Pu} /{ }^{240} \mathrm{Pu} / 241 \mathrm{Pu}=70 / 25 / 5$

ブランケット然料 ${ }^{235} \mathrm{U} /{ }^{238} \mathrm{U}=0.25 / 99.75$

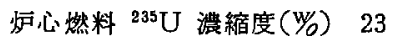

炻心燃料 $\mathrm{Pu}$ 富化度 $(\mathrm{W} / \mathrm{g})$

$\mathrm{PuO}_{2} /\left(\mathrm{PuO}_{2}+\mathrm{UO}_{2}\right) \quad 18$

炻心燃料菏荷 $(\mathrm{kg})$

$\begin{array}{llll}\mathrm{Pu} & 144 & { }^{235} \mathrm{U} & 160\end{array}$

炻心中性子束 $\left(\mathrm{n} / \mathrm{cm}^{2} \cdot \mathrm{sec}\right)$

平 均 $1.1 \times 10^{15}$

最 高 $1.9 \times 10^{15}$

增殖比 1.007

反応度保数(炉心部について)

Doppler 係数 $(T \cdot d k / d T)(\Delta k / k)-1.6 \times 10^{-3}$

燃料膨張係数 $\left(\Delta k / k /{ }^{\circ} \mathrm{C}\right)-4.9 \times 10^{-6}$

冷却材膨張係数( " $"$ ) $-7.0 \times 10^{-6}$

搆造材膨張係数( " $) ~-1.5 \times 10^{-6}$

$\mathrm{Na}$ ボイド係数 ( $100 \%$ 褧失時) $(\Delta k / k)$

$$
-2.5 \times 10^{-2}
$$

最大燃焼度 (燃料要素平均) (MWD/T) 25,000

护心余剩反応度 $\left(100^{\circ} \mathrm{C}\right)(\Delta k / k) \quad 0.045$ 以下

全制御棒反店度 $(\Delta k / k) \quad 0.06$ 以上

2. 熱特性

原子沪熱出力(第 1 期の原子沪出力)(MW) 50 层心部 46.8

軸方向ブランケット部 0.8

半径方向ブランタット部 2.4

出力密度 (平均/最大) $(\mathrm{kW} / l)$

怰心部 $200 / 366$

冷却材流量 (1 次冷却材) $(\mathrm{t} / \mathrm{hr}) \quad$ 約 2,200

冷却材温度 $\left({ }^{\circ} \mathrm{C}\right)$

原子师入口 370

原子炉出口 435

被覆管最高温度 $\left({ }^{\circ} \mathrm{C}\right)$ 約 560

燃料体最高温度 $\left({ }^{\circ} \mathrm{C}\right) \quad$ 約 1,800

燃料要素最大峃位長出力 $\left(\mathrm{W} / \mathrm{cm}^{-1}\right) 234$
3. 訬 心

炉心椹成要琹(本)

炻心燃料集合体数 67

半径方向ブランケット燃料集合体数 191

反射体(SUS-27製) 数 48

制御棒 $\left(\mathrm{B}_{4} \mathrm{C}\right.$ 製) 数 6

中性子源 1

炉心燃料集合体

炻心燃料要素型式 密閉式インテグラル型

炉心燃料部長さ $60 \mathrm{~cm}$

軸方向ブランケット部長さ(上下各) $40 \mathrm{~cm}$

集合体当り燃料要紊数 91本

燃料要素配列 正三角配列

燃料要案ピッチ $7.6 \mathrm{~mm}$

スペーサー型式 スパイラルワイヤ型

炉心燃料要素

蜘料体 U・Pu 混合酸化物焼結ペレット

ペレット径 $5.5 \mathrm{~mm}$

被覆材 SUS-32

被覆管外径 $6.3 \mathrm{~mm}$

被覆管肉厚 $0.35 \mathrm{~mm}$

半径方向ブランケット燃料集合体

燃料要素外径 $15 \mathrm{~mm}$

燃料部長さ $1,400 \mathrm{~mm}$

被覆材厚さ $0.6 \mathrm{~mm}$

集合体当り败料要素数 19 本

燃料要菜ピッチ $16.4 \mathrm{~mm}$

炉心高さ $60 \mathrm{~cm}$

的心等価直径 約 $73 \mathrm{~cm}$

軸方向ブランッット厚さ $40 \mathrm{~cm}$

半径方向ブランッット厚さ 約 $33 \mathrm{~cm}$

4. 炉 体

快容器

型 式 2 重壁方式

内 径 約 $3.6 \mathrm{~m}$

全 高 約 $10 \mathrm{~m}$

炻心支持板型式 2 重板

昵心構成要素支持方式 ハイドロリック。

回轱プラグ 2 重回転プラグ方式

ホールドダゥン方式

5. 冷却系

冷却回路数 2

主循環ポンプ基数（1次冷却系） 1 基/回路

中間熱交換器基数 1 基/回路

2 次主冷却主循環ポンプ基数 1 基/回路

空冷式主冷却器 1 式/回路

冷却材流量 $(\mathrm{t} / \mathrm{hr})$ 
1 次冷却系 約 2,200

2 次冷却系 約 2,200

中間熱交換器冷却材温度 $\left({ }^{\circ} \mathrm{C}\right)$

1 次冷却材入口 435

1 次冷却材出口 370

2 次冷却材入口 355

2 次冷却材出口 420
1 次冷却材量 $\left(\mathrm{m}^{3}\right)$ 約 183

2 次冷却材量 (11) 約 160

\section{6. 格納容器}

型 式 半 2 重格納方式
全 高 約 $55 \mathrm{~m}$
内 径 $28 \mathrm{~m}$

換器，2次冷却系空冷式冷却器からなりこの冷却系 統により炻心で発生した熱は大気に放散される。原子 师は6本の制御棒により制御され，原子炉本体扎よび これに直接付属している各種の機器類は鋼製の気密格 納容器内に収納されている。以下高速実験炻の各部に ついてその概要を簡単に述へる(第 2 表)。

1. 炉心構 成

高速実殹炉の炉心は，炉心燃料集合体，半径方向ブ ランケット燃料集合体，反射体，制御棒などによって構 成されている。炉心の断面图を第 1 図に示す。

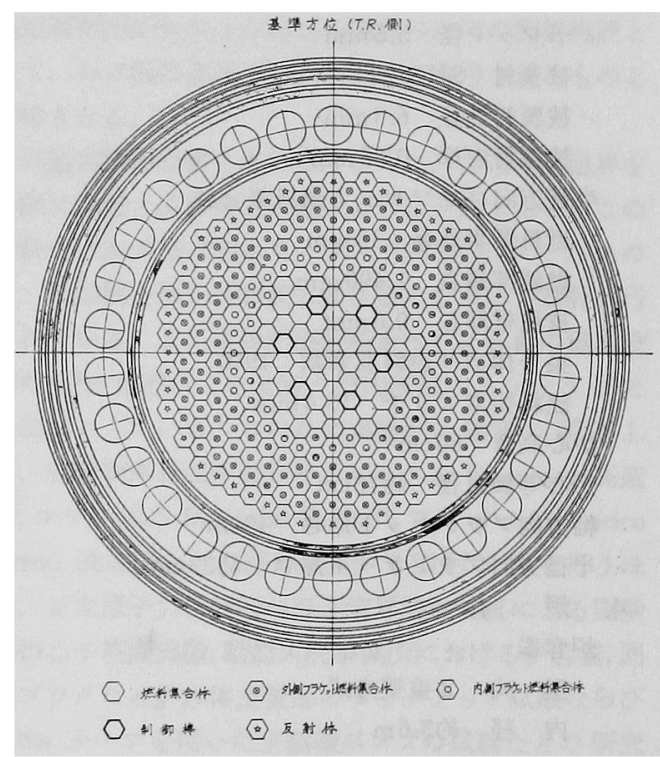

第1図亚心部棈成図

\section{（1）弱心燃料集合体}

炉心燃料集合体は，91本の炉心燃料要素をピッチ $7.6 \mathrm{~mm}$ で三角形に配列 し, 内面距離 $74.7 \mathrm{~mm}$ ，肉厚 1.8 $\mathrm{mm}$ の六角形のステンレス鋼製鞘に収めたるので，そ の概略を第 2 图に示す。炻心燃料要素は中心部約 60 $\mathrm{cm}$ の長さの部分が质心燃料部であり，その上下それ ぞれ $40 \mathrm{~cm}$ は軸方向ブランケット部，最上端約 $40 \mathrm{~cm}$ 然焼に伴って発生する核分裂生成ガスをためるための ガスプレナムである。

炉心燃料要素中，炉心燃料部はU・Pu の混合酸化物

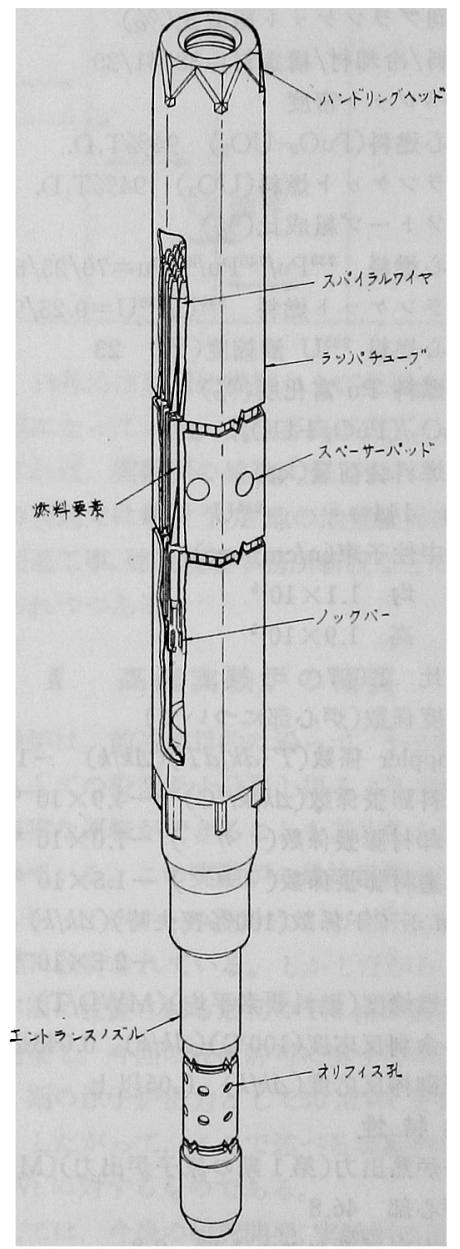

第 2 图叔心燃料菓合体

を焼結した直径 $5.5 \mathrm{~mm}$ のペレットよりなり，軸方向 ブランケット部は同じ直径の減損Uの酸化物ペレット で，これらを被覆している被覆管は外径 $6.3 \mathrm{~mm}$ ，肉厚 $0.35 \mathrm{~mm}$ のステンレス鋼管である。炉心燃料要素はい わゆるスパイラルワイヤ方式インテグラル型で, 各然 料要素の間隔を正確に保つために被䥅管の外表面に直 径 $1.2 \mathrm{~mm}$ のステンレス製のワイヤを巻きつけてあ る。

（2）半径方向ブランケット燃料集合体 
半径方向ブランケット燃料集合体は19本の半径方向 ブランケット燃料要素をピッチ約 $16.4 \mathrm{~mm}$ で角形に 配列し，炉心燃料集合体の鞘と同型のステンレス鋼製 䩗に收めたすのである。半径方向ブランケット燃料要 素は，直径 $13.6 \mathrm{~mm}$ の減損Uの酸化物烧結ペレットを 肉厚 $0.6 \mathrm{~mm}$, 外径 $15 \mathrm{~mm}$ のステンレス鋼管に収めたる ので, 各要素には間隔保持のために炉心燃料要素同様 ステンレス鋼製ワイヤを巻きつけてある。

(3) 反射体

反射体は中心に穴があるステンレス鋼製六角棒で， その外形は师心燃料集合体に類似している。

(4) 制 御 棒

原子帅の出力を制御する制御棒は第 1 図に示すよ5 に炉心領域に対称に 6 本配置されている。1 本の制御 棒は ${ }^{10} \mathrm{~B}$ を高濃縮した炭化ホウ素ぺレット中性子吸 収材をステンレス鎆管に収めたるの7本からなり，吸 収材部の長さは $70 \mathrm{~cm}$ である。制御棒の構造は 6 本と

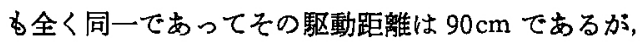
使用上は安全棒と調整棒に分けて使われる。制御棒は ボールナットスクりニー方式で駆動されるが，原子炉 の轳急停止時にはパネ力で加速されて速やかに沪内に 插入される構造になっている。

炉心燃料の $\mathrm{UO}_{2}$ と $\mathrm{PuO}_{2}$ の混合比は82:18であり。 Uの濃縮度は23\%である。Puの組成は ${ }^{239} \mathrm{Pu}:{ }^{240} \mathrm{Pu}$ : ${ }^{241} \mathrm{Pu}=70: 25: 5$ 在予定している。原子炣内に装荷 される师心燃料集合体数仕67本，半径方向ブランケッ 卜燃料集合体数は 191 本，反射体数は48本である。こ の場合の师心の大きさは，等価直径約 $73 \mathrm{~cm}$, 高さ 60 $\mathrm{cm}$ で炉心の体積は約250 $l$ である炉心に装荷される 全 $\mathrm{Pu}$ 量㹥約 $140 \mathrm{~kg},{ }^{235} \mathrm{U}$ の全量は約 $160 \mathrm{~kg}$ である。ま たブランケット燃料として用いられる減損Uの全量は 約 $8 \mathrm{t}$ である。

$\mathrm{Na}$ 冷却材は燃料集合体の下部から $370^{\circ} \mathrm{C}$ の温度で 入り，燃料要素を冷却しながら集合体内を約 $5 \mathrm{~m} / \mathrm{sec}$

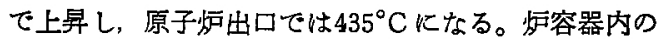
$\mathrm{Na}$ 液面上は $\mathrm{Ar}$ ガスで満たされている。 $\mathrm{Na}$ 冷却材 の流量は, 炉内での発熱量の分布に適応するように, 中心部で大きく周辺部ては小さくなるように設計さ れている。また燃料集合体は师心の下方に設けられた 燃料集合体支持板に㧴入されて自立しており，Naの 流れによる集合体の浮上りは流体力学的に防止される 構造になっている。

高速実験炉の炉心の核特性は安全性を考慮して，温 度係数, $\mathrm{Na}$ ボイド係数, Doppler 係数などの各種の反応 度係数がすへて真の值をすつょうに設計されている。

\section{2. 师体構造}

炉心を中心とする原子少炉体構造は，できるだけ可 動部分を少なくし，簡単な構造にすることによって安 定な運転の信頼性を高めるよう設計されている。师心 を収納する原子炉容器は内径 $3.6 \mathrm{~m}$, 高さ $10.5 \mathrm{~m}$, 板厚 $2.5 \mathrm{~cm}$ のステンレス鋼製の円筒型容器であり，炉体構 造を第 3 图に示す。炉容器は 2 重壁構造で，その間裳 には $\mathrm{N}_{2}$ ガスを満してあり,万一内壁から Naが漏洩し た場合にる $\mathrm{Na}$ を保持するととるに，怔容器への $\mathrm{Na}$ の注入時には原子炉容器を $\mathrm{N}_{2}$ ガスによって余熱する よう設計されている。原子炉容器下部には Na 冷却材 入口孔が設けられ，上部には冷却材出口孔中補助冷却 系, 炉容器内の $\mathrm{Na}$ 液面を一定に保つための才ーハー フロー系，Ar ガス系などのための配管が接続されて いる。

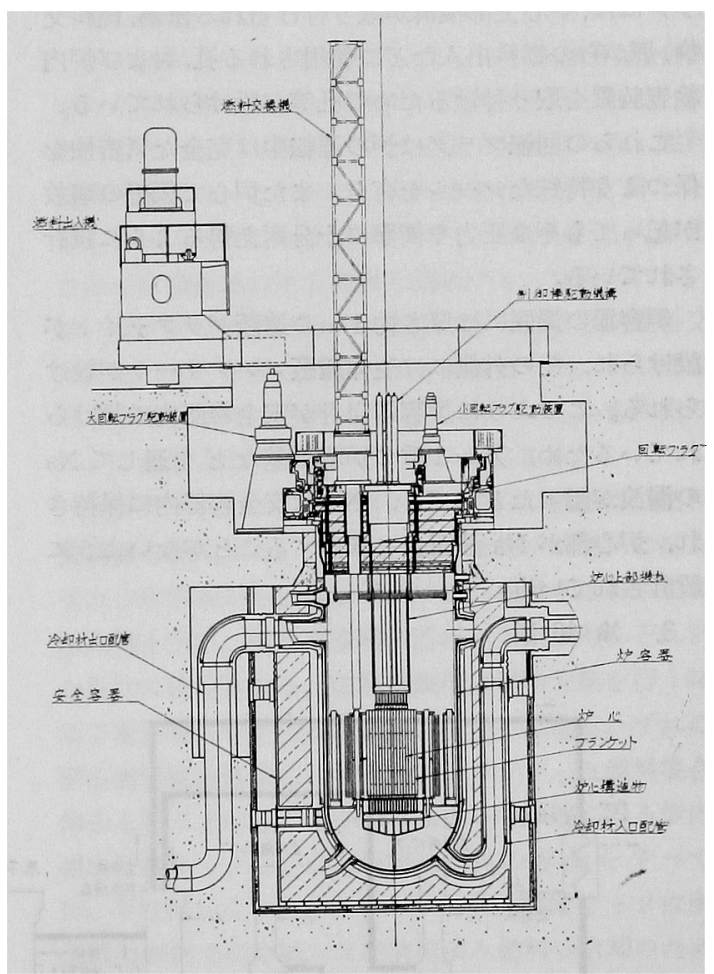

第 3 图原子炉本体断面図

炉容器内におかれる炉心の周囲には，使用斉み燃料 を一定期間炉内で朎却するための燃料貯蔵ラックが設 けられ，その外側には帅容器を放射線から保護するた めの鋼製遮蔽板があり，炉容器内壁のすぐ内側には炉 容器材の耐放射楾試験片等を照射するための材料照射 ラックが設けられている。少心の下部には，炉心を支 持するととるに Na 冷却材の高压プレナムを構成する 
炉心支持板と支持棈造物が設けられる。炻心上部には 燃料集合体の出口冷却材温度を測定するための熱電対 や制御棒駆動機構を装備した炋心上部機構が出りこ の炉心上部機粠は炉容器の蓋である回転プラグに取り 付けられている。

回転プラグは大小 2 つの回転可能なプラグであり， 吙心からの放射楾を遮蔽するとともに，燃料交換時に は燃料取扱器を炉心の任意の位置に正しく位置つけで きるょうにするためのすのである。大回転プラグは直 径約 $4.7 \mathrm{~m}$, 回転範用 $\pm 180^{\circ}$, 小回転プラグは直径約

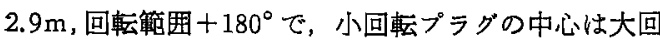
転プラグの中心上り $50 \mathrm{~cm}$ 偏心しており，それぞれ独 立にモータにより駆動される。大小回転プラグはステ ンレス鋼, 炭素鋼, 黒鉛などの遮蔽層からなり，厚さは 約 $2.5 \mathrm{~m}$ で内部は $\mathrm{N}_{2}$ ガスにより冷却される。小回転プ ラグには，炬心上部機構が取り付けられるほか，燃料交 換, 惊からの燃料出入などに使用される孔。括よび炻内 検查装置を取り付けるための孔等が設けられている。

これらの回転プラダは怰の運転中は完全な気密性を 保つよう特殊なシールを有し，また炻心で仮想の事故 が起ってもその珐力や衝撃に十分耐光得るよ5に設計 されている。

归容器の周囲には厚さ約 $1 \mathrm{~m}$ の遮蔽グラファイトが 設けられ，その外側には生体遮蔽コンクリートが設け られる。このよ5に炉容器自身が安全容器内に設けら れているため, 万一 2 重の炉容器壁などを通してNa の漏洩が起ったとしても， Na は安全容器内に保持さ れ，炻心部が $\mathrm{Na}$ 液面上に露出することがないよ5に 設䛨されている。

3. 冷却系
高速增殖沪の冷却材として Na が使用されるのは，

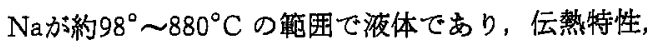
流体特性が良好で高出力密度の昵心冷却に適している こと，中性子の減速作用が小さく高速炉の冷却材とし て適していることなどの利点があるからである。その 反面，水や空気と激しく反忘すること，中性子を吸収 して放射性となり強い $\boldsymbol{r}$ 線を出すこと，不透明である ため怰内の然料交換などに特殊の土夫を必要とするこ と，常温で固体であるため原子师の停止時などには加 熱する必要があること，などから高速炉の冷却系は従 来の軽水师などに比ぺて著しく異なり，Na技術と呼

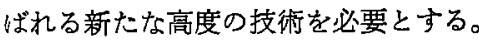

実験师の冷却系は主冷却系と補助冷却系とからな り; それぞれ 1 次冷却系と 2 次冷却系とで構成されて いる。主冷却系, 補助冷却系の 1 次冷却系の Na怯炬内 を循環し，中間熱交換器を介してそれぞれの 2 次冷却 系に熱を伝達する。主冷却系は 2 回路あり，それぞれ 循環ポンプおよび中間熱交換器を有しており，その概 略を第 4 图に示す。冷却材 $\mathrm{Na}$ の流量は 1 回路当り約 1,080 t/hr である。主冷却系を 2 回路設けるのは, わ が国の $\mathrm{Na}$ 技術の現状から見た機器製作上の便宜，拉 よびポンプなどの機器故障時に怙ける炉心冷却の確実 性の保証などを考虑して採用されたるのである。また 1 次冷却系 Na は师心を通るさい放射化されるので， 中間熱交換器により非放射性の Na に熱を伝達したの ち空気冷却器を使用する方式が操用されている。

1 次冷却系の配管は寸べて 2 重管になって括り，内 管か破れても Na が外部に流出しない構造となってい る。内外管の間隙は $\mathrm{N}_{2}$ ガスで満されており，この $\mathrm{N}_{2}$ ガスは师容器の場合と同じように，予熱用として用い

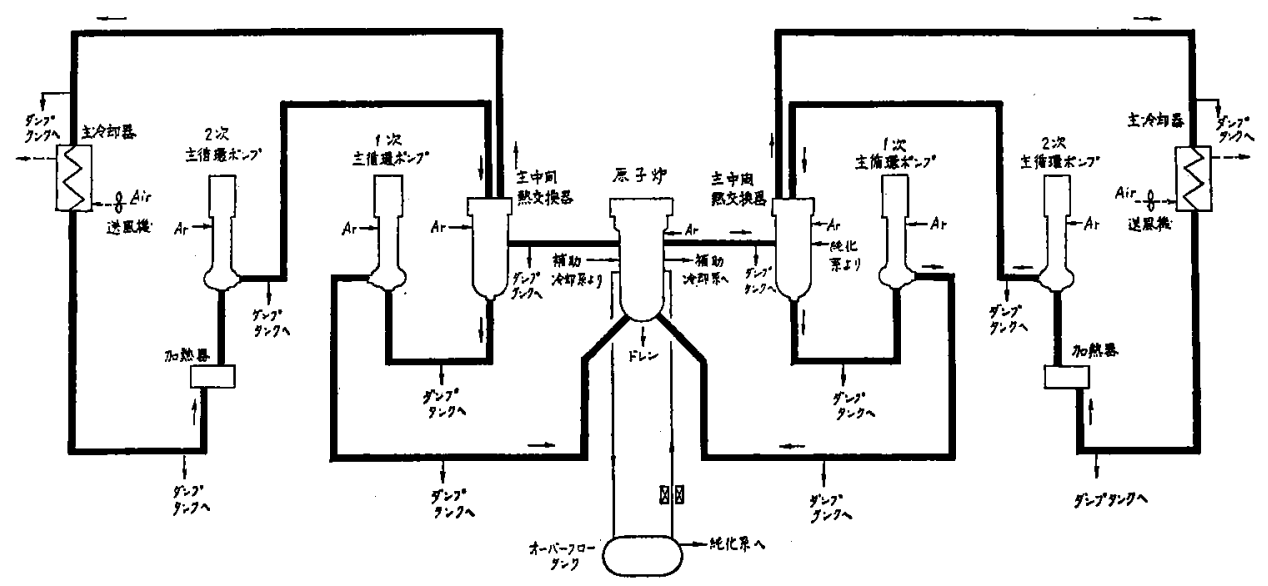

第 4 図主冷却設備系統説明図 
られるほかNa の漏洩を監視するととるに, 漏洩する $\mathrm{Na}$ が直接外部雾囲気と接触することを防止するのに 用いられる。2次冷却系は中間熱交換器を介して伝達 される 1 次冷却材 $\mathrm{Na}$ の熱を空冷式主冷却器に上り大 気中に放散させるためのるのであり，2 次冷却材 $\mathrm{Na}$ 流量は 1 次冷却系の流量にほぼ等しい。補助泠却系は 主冷却系がその機能を品失した時に炉心を冷却して炉 心内の核分裂生成物の崩壊熱を除去するための椧却系 であり，主冷却系と同じように中間熱交換器および 2 次冷却系を備えている。補助冷却系の除熱能力は約 2.6MW であり，ポンプは䉓磁ポンプである。

主冷却系の循環ポンプは, 1 次冷却系用, 2 次冷却 系用とるに綐軸自由液面型遠心式の機械ポンプであ る。ポンプ内の Na 液面上は Arガスでカバーされて おり，軸封はAIガスを注入して Na 蒸気の漏洩な防 止する構造となっている。

中間熱交換器は縦置自由液面シェル・アンド・チュー ブ型で， Na 液面は Ar ガスでカバーされる。1次冷 却材 $\mathrm{Na}$ は胴側に入り，2次冷却材 $\mathrm{Na}$ は管側を通 る。2 次冷却材 $\mathrm{Na}$ は 1 次冷却材 $\mathrm{Na}$ 上り 高生で循 環するので，中間熱交換器に故障を生じた際には放射 性の 1 次冷却材 $\mathrm{Na}$ 放非放射性の 2 次冷却村 $\mathrm{Na}$ に混 入する危険性は少ない。2 次冷却材の中間熱交換器の

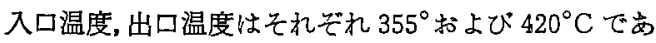
る。主冷却器はフィン付空冷多管式でめり, 主冷却系 1 回路当り 4 基設けられる。

高速実験炉の各冷却系統に用いられる $\mathrm{Na}$ を常に高 純度に保つために， $\mathrm{Na}$ 中の不純物，主として酸化物 を除去するコールド・トラップを含む $\mathrm{Na}$ 純化系が設 けられる。コールド・トラップは $\mathrm{Na}$ の温度を適当な 值にまで低下させて不純物を析出除去するすのて，不 純物の濃度はプラギング計により監視される。これら の設備により冷却材 $\mathrm{Na}$ は常に高純度に保たれ，不純 物による $\mathrm{Na}$ 流路の閉塞や材料の腐食が防止される。

原子师内の $\mathrm{Na}$ の流れは 2 つに分岐される。炉心部 は発熱量か大きく，师出力の約 $90 \%$ を発生するので多 量の冷却材を必要とするが，半径方向ブランケット部 は発熱量が小さいので，それぞれの領域の発熱量に相 応した流量の Naを流すことによって炉心内の温度分 布が適正になるよ5設計されている。

炉心部を流れる Na は，高生プレナムから炉心燃料 集合体脚部の側面に設けられた孔に流入し，炉心然料 集合体を冷却しつつ上昇する。高圧プレナムの圧力は 1 次冷却系主循環ポンプの吐出圧力とはほ同一であ る。半径方向ブランケット燃料集合体を流れる Na は,
反射体脚部に設けられたオリフィスにより䯩圧プレナ ムから低圧プレナムに流入し，ブランケット燃料集合 体の脚部底面から集合体内に流入する。低压プレナム の圧力は高圧プレナムの約 $1 / 4$ 程度である。これらの各 燃料集合体を流れる Na は炻心の上方で合流し，炻容 器の Na出口ノズルから 1 次冷却系配管により中間熱 交換器へ導かれる。

师内の $\mathrm{Na}$ 液面は，炉上部の回䎐プラグなどに接触 しないよう，オーバー・フロー系により常に一定に保 れれオーパーフローした Na 蝤管によりオーハ 一・フロータンクに導かれる。また $\mathrm{Na}$ 液面は $\mathrm{Ar} カ ゙$ スによりカパーされ，液面のさざ波はディッププレー

トにより防止される。

これらの原子炉の全冷却系に必要な $\mathrm{Na} の$ 総量は約 $400 \mathrm{~m}^{3}$ と見込まれている。

\section{4. 燃料交換}

炉心燃料集合体，半径方向ブランケット燃料集合体

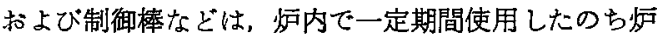
外に取り出され，新しいるのと取り換えられる。燃料 交換系設備は，これらの 1 連の作業を行う設備で り，炉内での燃料の交換，原子炉への燃料の出入は熱 ならびに放射線に対し厳重な遮蔽のるとで行われる。 $\mathrm{Na}$ 泠却弱の燃料取扱いは従来の軽水帅などの燃料交 換に比べると複雑な機器操作を必要とする。その理由 は Na が化学的に活性が強く，不透明で，しか子炉内の $\mathrm{Na}$ は高温で放射化されているからである。

害験炉に抋いては，炉容器での然料の移動には然料 交換機を使用する。しかし，炉容器内への燃料の挿入 または炉容器からの取出しには別な機械すなわち燃料 出入機を用い，燃料交換機と燃料出入機はそれぞれ別 な目的に使用される。燃料交換機は燃料交換を行う時 に2 重回転プラグ上に設置され，忓内にあるいずれの 师心燃料集合体または半径方向ブランケット燃料集合 体をる吊り上げることができ，炣心の周囲にある炉内 然料眝蔵ラックと师心との間の燃料の移動をすへて $\mathrm{Na}$ 中で行うことができる。炉内燃料貯蔵 ラックは新 燃料の炉内での中継招よび使用済み燃料の冷却のため に使用される。

燃料出入機は，レール上を走行するプリッジ上に設 けられた台車に取り付けられ，緃方向扎よび横方向に 移動することができ，哣容器とトランスファロータと の間の燃料の移送に用いられる。トランスファロータ は原子炉格納容器内に燃料を出入するための燃料の中 継器で, 新燃料の一時的な貯蔵と使用済み燃料の彾却 のためにる使用される。トランスファロータと新燃料 
詝蔵室または使用済み燃料貯蔵設觜との間の燃料の移 送は自走式の燃料取扱いキャスクカーによって行われ る。

使用济み燃料は，燃料に付着している $\mathrm{Na}$ を洗浄 し たのら水プールに入れて眝蔵，冷却する。

\section{5. 計 測 制御}

高速実験炉の制御系は，原子炉出力制御設備とプラ ント制御設備とからなる。原子炉出力制御系は制御棒 によって炉出力る制御する系㓍で，燃料の燃焼や運転 条件の変化に伴 5 反応度の変動を補儧 し，原子师を制 御するるのである。プラント制御系統は，泠却材 $\mathrm{Na}$ の流量を一定に保つととすに, 空冷式の主冷却器の風 量を制御して原子师の入口の冷却材 $\mathrm{Na}$ 温度崌一定に 保つよ 5 制御するるのである。これらの制御系は，中 性子計装系, 原子炉保護系,プロセス計装系などより構 成されている。

中性子計装系㤝，原子师の起動, 運転, 停止の際に必 要な炉内の中性子束密度, 原子师周期などを指示, 記録 する装置であり，起動系，中間出力系少よび線型出力 系などより構成される。原子炉保護系は，原子炉の安 全な運転を磪保するためのるので，万一異常な事態が 発生した場合に原子师を安全確実に制御する機能を有 し，原子炉施設执よび人員の安全を確保するるのであ る。この原子炉保讙系は，制御棒の插入に上る原子炉 出力の減少, 原子师格納容器を貫通している各種の配 管やダクトなどの閉切りなどの動作を自動的に行わせ るはか，運転員の誤操作を防止するための各種の連錠 機構を有しており，フェイルセイフの原理に基づいて 設計されている。

ブロセス計装は, 各種の機器の動作状態, 各所にお ける冷却材 $\mathrm{Na}$ ○ Ar ガスなどの温度, 圧力, 流量など の計測を行う設備て，原子炉の運転に必要なこれらの 情報を指示あるいは記録させるすのである。温度計と しては通常の熱電対などが測温体に用いられるが，冷 却材 $\mathrm{Na}$ の流量計には電磁流量計が用いられ，また $\mathrm{Na}$ の漏洩を監視するための漏洩検出器が各所に設け られる。

高速実験师に設けられる破損燃料検出装置は次の 2 種類のるのか設けられる。その 1 つは，破損然料から 冷却材 $\mathrm{Na}$ 中に放出される核分裂生成物からの遅発中 性子を検出して燃料の破損を椧知しようとする装置で ある。他の 1 つは，冷却材 $\mathrm{Na}$ をカパーしている $\mathrm{Ar}$ ガス中に混入してくるガス状の核分裂生成物を検出す ることで然料の破損を検知しょ5とする装置でる。

これらの各計测制御系は，原子归付属建物の東北隅
に設けられる中央制御室に集中され，原子少の運転制 御は中央制御室で行われる。

\section{6. 噔棄物处理}

高速実険师の各施設から排出される気体, 液体, 固体 の各種廃棄物はそれぞれ区分されて，適切に処理，好 分される。気体廃㲤物の主なるのは冷却材 $\mathrm{Na}$ をガ 一している Ar ガス系設備からの排気ならびに各建物 からの排気などである。これらの排気のうち放射能レ ベルが充分低いすのは排風機室に集めてフィルタで沪 過したのち希釈し，高さ $80 \mathrm{~m}$ の排気筒から放出する。 Ar ガス系などからの放射性の排気は，原子炉付属建 物内の地下室に設けられた眝留タンク内に圧縮眝留し て放射能を隇容させることができるよう設計されてい る。放射能が隇衰したらフィルタで沪過し希釉して排 第筒から放出する。

液体廃棄物の主なるのは，燃料取扱系設備から排出 される洗浄廃液, 機器保修のさいの機器洗浄廃液など である。これらの廃液は，放射能のレベルに応じて貯 留され，あるいは希釈してモ二タした後排水溝へ放出 される。また放射能が規定濃度以上のるのは総合廃血 物処理場へ輸送されて処理される。なお，高速実験师 はPu を含む燃料を使用するのて，廃育物処理建物内 に $\alpha$ 線を放出する核種を含さ廃液を処理する設備をる 設けている。

固体廃棄物は，中·低レペルの放射能のるのはプラ スチックなどの袋に入れて眝蔵され，高レベルのもの は金属性容器に入れて貯蔵される。これらの眝蔵室は 廃棄物処理建物内に設けられている。

\section{7. 原子炉格納施設}

原子炉格納施設は，原子炉，1 次冷却系設備，燃料出 入機，燃料交換機などを格納する原子炉格納容器およ びその外周に設けられている外周コンクリート壁より なる。格納施設は，原子师から放射性物質が放出され てるそれる格納容器内に密封することによって，原子 帅の周辺の公衆の安全を確保するための施設である。 したがって，高速実験炉の格納施設は，万一 $\mathrm{Na}$ 漏洩 事故が起り，それに引き続いて Na の火災が発生して 格納容器内の温度や圧力が上昇すると仮想した場合て る，格納施設としての機能が損われることのないよう に設計されている。

格納容器は銅製で，乙の頭部は半径 $14 \mathrm{~m}$ の半球形, 胴部は円筒, 底部は半棈円形である。全高は約 $60 \mathrm{~m}$, 地 上高約 $30 \mathrm{~m}$ ，内径は約 $28 \mathrm{~m}$ である。格納容器胴部の外 周はコンクリート壁によって囲まれており，間隙は常 に負圧に保たれている。すなわち，格納施設は第 5 図 


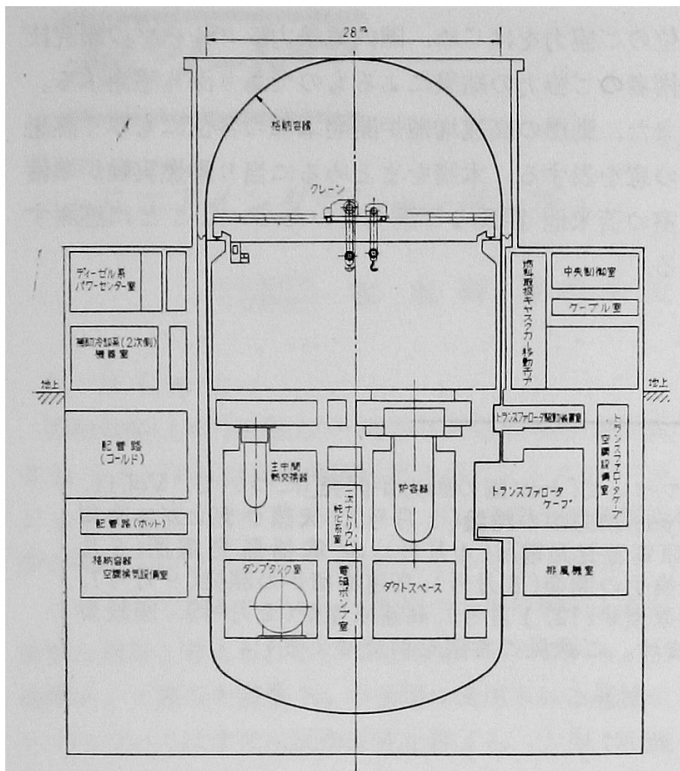

第 5 図原子炬建物綐断面図

に示すようにいわゆる半 2 重棈造である。格納容器へ の出入口には気密性を保つためすべて気密扉が用いら れる。すなわち, 所員の通常用出入口および非常用出 入口はとすに2 重扉であり，いずれる片方の扉が閉じ なければ一方の扉が開かない構造で，両側の気圧を等 しくするための圧力平衡弁が設けられている。機器搬 入用の入口る亡た気密屝である。

格納容器から原子炉付属建物などの他の建物につつ く配管,ダクトなどには必要な個所に隔離弁が設けら れており，事故時にはこれらの弁を閉止して格納容器 と外部とを遮断する上ら設計されている。格納容器内 の操作床面は敷地面とはは同じて，操作床面より上は 通常の空気雾囲気である。燃料交換機，燃料出入機な ぞの機器以外，原子炉容器，1次椧却系機器などの主 要な機器類はすべて操作床面下に設置され，操作床面 下の空間は万一の Na 漏洩儿上る火災を防止するため 通常時は $N_{2}$ ガスで満たされている。

また, 格納容器の上部には重量機器を取り扱うため の150 t 用旋回クレーンか装備されている。

\section{8. 建物配 置}

高速実験炉は動然大洗事業所内の敷地約 $60,000 \mathrm{~m}^{2}$ を 使用して設置される。施設の全体の配置は第 6 図に示 すように，原子沪格納容器を中心とする原子炉建物を 中央に, 研究管理建物, 主冷却器建物, メンテナンス建 物, 廃衰物処理建物などの各建物が配置され，将来建 設を予定されている燃料集合体検查施設の敷地方確保

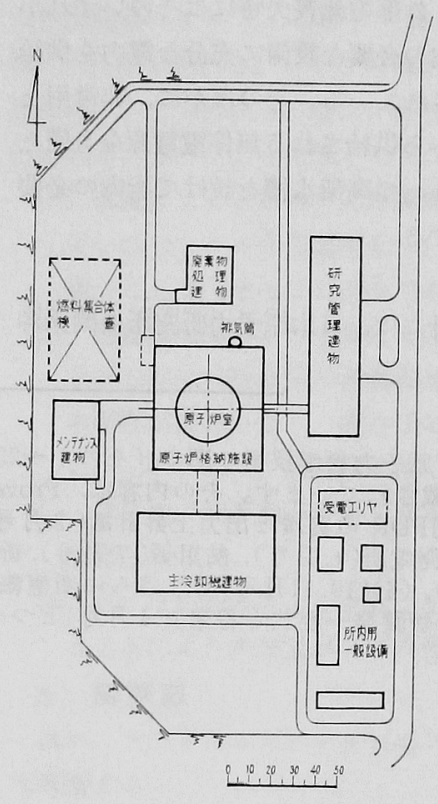

第 6 図原子师施設全体配置図

きれている。

原子炉格納容器内は中心よりやや北側に偏して原子 炉容器肪あり, その北側の格納容器壁境界にトランス ファロータがあり，つついて新燃料および使用済み燃 料を取り扱う燃料取扱い設備が設けられている。格納 容器内の原子归容器の南側には中間熱交換器, 1 次冷 却系循環ポンプ等が設けられ，てれから主椧却器建物 まで 2 次冷却系配管がのびている。

格納容器を取り围さ原子炉付属建物内には，北側に は燃料取扱い設備のほか中央制御室, 排風機室、放射線 管理室, 廃ガスタンク室などが設けられ，南側には非常 用ディーゼル発電機室, 非常用ハシッテリー電源室, 補助 冷却 2 次系機器室, $\operatorname{Ar}$ ガス系機器室, 1 次冷却系 $\mathrm{N}_{2}$ ガス予熱系機器室, 格納容器空調機器室, 廃液タンク室 などが設けられる。

主冷却器建物には 2 次冷却系機器, Ar ガス供給設 備, $\mathrm{N}_{2}$ ガ大供給設備, $\mathrm{Na}$ 供給設備などが設置されて いる。 8 基の空冷式主冷却器は建物の南側に 1 列に配 置される。メンテナンス建物は譏器を保修するための 建物て，保修すべき機器はここに搬入され，Na の除 染, 分解点検, 補修等の作業が行われる。廃棄物建物に は，廃液眝槽，固体廃㶳物貯蔵庫等が地下室に設けら れ，廃液処理設備等は地上に設けられている。

電源は商用 $66 \mathrm{kV}$ を受電し, $3.3 \mathrm{kV}$ に降玌して所 内電源とするととるに, 非常用電源としてディーゼル 
発電機を 2 台設け，外部電源喪失時にはそのいずれか 一方の電力で施設内の必要な設備に充分な電力を供給 できるように設計されている。そのほかに, 非常用と してはバッテリーから供給される無停電電源をる備え ている。給水は $100 \mathrm{t}$ の高架水槽劣設けて所内の必要 な個所にのみ供給する。
位のご協力をはじめ，国内原子力 5 グループの研究技 術者のご協力の結果によるるのであり深く感謝する。 また，動燃の高速増殖炉開発本部の各位にる厚く感謝 の意を表する。本講をまとめるに当り動燃実験炉準備 室の苫米地 顕氏のご協力をいただいたことに感謝す る。

高速実験师の設計には，日本原子力研究所の関係各

本辚座は，「原子力科学技術の進歩」(その 1〜25)につついて「わが国の動力恼開発」について，Vol.11， 1 月号らか連載されています。その内容は, Proven Type 動力炉の総論 ( 1 月号), 天然ウランガス冷却 灯 ( 2 月号)，JPDR の実精と出力上昇計画( 3 月号)，原電敦賀発電所 ( 4 月号)，東電福島発電所 ( 5 月 号), 関電美浜発電所 ( 6 月号), 舶用炉 ( 7 月号), 新型転換炉の開発( 8 月号), 高速增殖哣の開発 ( 9 月号), 高速実験炉 (I)，(I) $(10,11$ 月号)で，さらに新型転換炉原型炉 $(12 ， 1$ 月号), 高速原型炉 ( 2 月号), 座談会 「わが国の動力炉開発一現状と将来」( 3 月号)とつづきます。ご意見ご希望をお奇せ下さい。

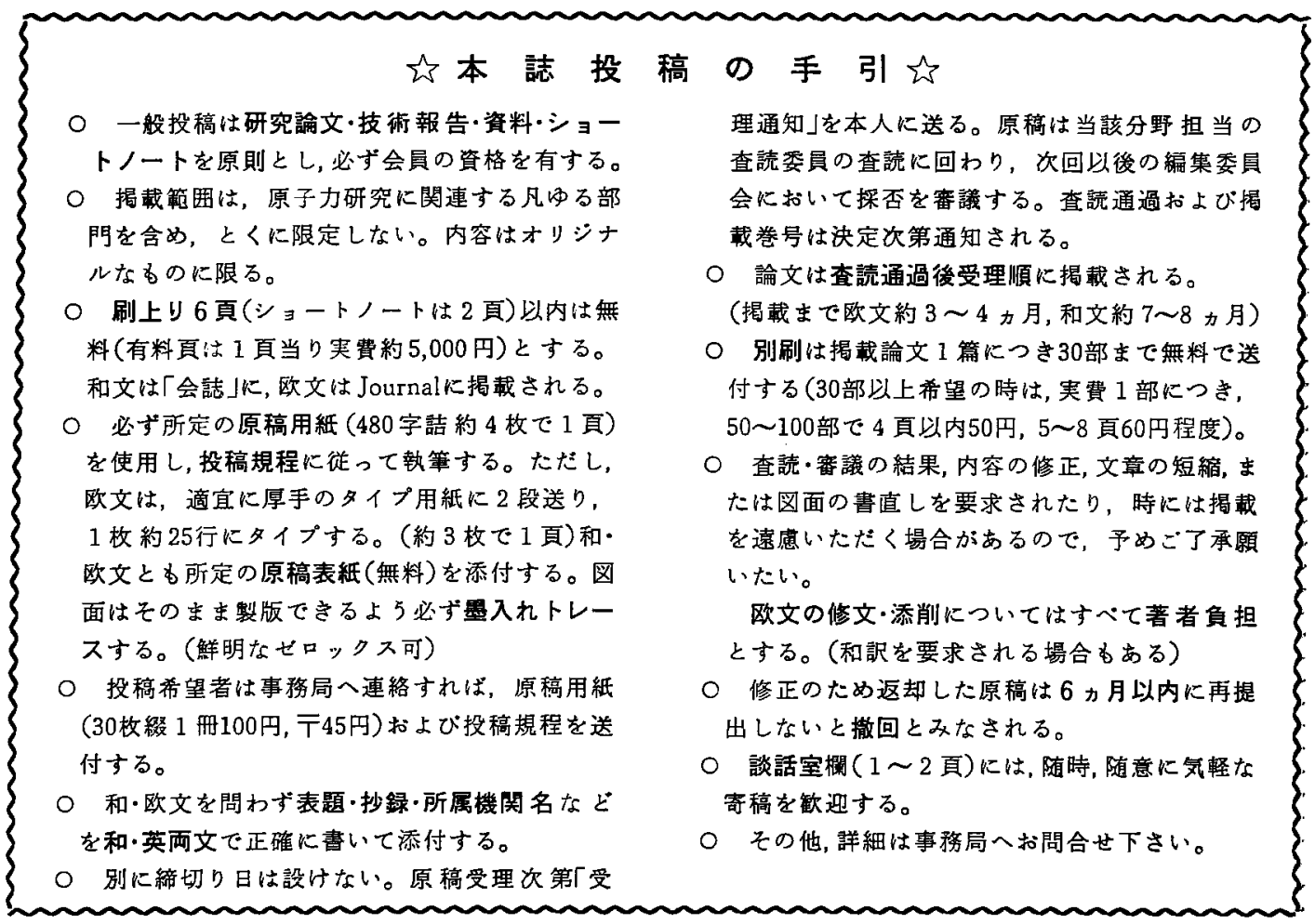

